\title{
ANTIPROLIFERATIVE AND DNA CLEAVAGE ACTIVITY OF VARIOUS SOLVENT EXTRACTS OF ACACIA FARNESIANA LINN. POD
}

\author{
SOUL SHEKHAR SP ${ }^{1}$, MANJULATHA K ${ }^{2}$, SATYANARAYAN ND ${ }^{1 *}$ \\ ${ }^{1}$ Department of Pharmaceutical Chemistry, Kuvempu University, Postgraduate Centre, Kadur, Karnataka, India. ${ }^{2}$ Department of \\ Biochemistry, School of Life Science, University of Hyderabad, Gachibowli, Hyderabad, Telangana, India. Email: satya1782005@gmail.com
}

Received: 03 May 2017, Revised and Accepted: 26 May 2017

\section{ABSTRACT}

Objective: Cancer has become the major disease by uncontrolled cell growth effecting large population on the globe. This study, deals with antiproliferative activity of different solvent extracts, viz., n-hexane $\left(\mathrm{S}_{1}\right)$, dichloromethane (DCM) $\left(\mathrm{S}_{2}\right)$, and methanol $\left(\mathrm{S}_{3}\right)$ of Acacia farnesiana pod on four cancer cell lines, viz., chronic myelogenous leukemia (K562), breast cancer (MCF-7), hepatocellular carcinoma (HePG2), colorectal adenocarcinoma (Colo 205), and DNA cleavage activity of the extracts on CT-DNA.

Methods: The antiproliferative study was performed by MTT assay and DNA cleavage studies of the solvent extracts $\left(\mathrm{S}_{1}, \mathrm{~S}_{2}\right.$, and $\left.\mathrm{S}_{3}\right)$ and its fractions $\left(\mathrm{S}_{4}\right.$ and $\mathrm{S}_{5}$ ) was carried out by agarose gel electrophoresis method.

Results: The antiproliferative activity results revealed that n-hexane extract ( $\left.\mathrm{S}_{1}\right)$ has showed activity against MCF-7 (21.70 \%) cell line and methanol extract $\left(\mathrm{S}_{3}\right)$ against K562 (24.5\%) and HePG2 (23.3\%) cell lines. The DNA cleavage could be seen at every concentration tested by n-hexane $\left(\mathrm{S}_{1}\right)$, DCM $\left(\mathrm{S}_{2}\right)$, and methanol $\left(\mathrm{S}_{3}\right)$ extracts and significant cleavage was observed at concentrations of 25,50 , and $100 \mu \mathrm{g}$ by fractions $\left(\mathrm{S}_{4}\right)$ and $\left(\mathrm{S}_{5}\right)$ of methanol extract.

Conclusion: The results indicated that the extract of A. farnesiana pod (n-hexane and methanol) has antiproliferative properties and the DNA cleavage studies performed on CT-DNA was found that the extracts and its fractions showed significant activity at the concentrations tested.

Keywords: MTT assay, CT-DNA, Ethidium bromide, Agarose gel electrophoresis, Leukemia, MCF-7 cell line, K562 cell line, HePG2 cell line.

(C) 2017 The Authors. Published by Innovare Academic Sciences Pvt Ltd. This is an open access article under the CC BY license (http://creativecommons. org/licenses/by/4. 0/) DOI: http://dx.doi.org/10.22159/ajpcr.2017.v10i9.19548

\section{INTRODUCTION}

Cancer is one of the most severe diseases in which deregulating proliferation of abnormal cells is invading and disrupting surrounding tissues [1]. It begins in the cells of the body, where the orderly process is disturbed by producing new cells which are not needed and old cells do not die thus these extra cells lump together to form a growth of tumor [2]. It is the leading cause of morbidity and mortality worldwide with approximately 21.7 million new cases, 13 million cancer-related deaths and is expected to rise by $70 \%$ around 2030 was reported by American Cancer Society; 2015 [3]. The partial success of clinical therapies including radiation, chemotherapy and surgery in the treatment of cancer, indicates that there is an urgent need of alternative strategies to control cancer [4]. Medicinal plants have been used as a remedy for treating of human diseases for centuries, because of their production of new chemical entities as secondary metabolites of therapeutic value [5] such as alkaloids, flavonoids, tannins, and phenolics [6]. The secondary metabolites display significant activities and play a key role in the treatment of cancer [7]. Medicinal plants have become a focal point and an important alternative to develop the present and future health requirements against cancer; this is because secondary metabolites of plants could maintain the health and has the ability to cure various diseases, including cancer with less harmful effects [8]. In this regard Acacia farnesiana, a medicinally important plant was considered for its preliminary investigation for cancer therapy.

A. farnesiana (Linn.) Willd., (Family: Fabaceae) is a thorny bush or small tree grows up to $8 \mathrm{~m}$ tall throughout tropical parts of Indian subcontinent, especially in sandy soils of river beds around north and south India [9]. Morphologically the bark is rough and light brown in color. Branches are glabrous, purplish to gray, with extremely small glands. Stipules are spinescent, usually short, up to $1.8 \mathrm{~cm}$ long, rarely longer, never inflated.
Leaves are twice pinnate, with a small gland on petiole and frequently one on the rachis near top of pinnae. Pinnae are 2-8 pairs and leaflets are 10-12 pairs which are minute, $2-7 \mathrm{~mm}$ long, $0.75-1.75 \mathrm{~mm}$ wide, glabrous, leathery. Flowers are in axillary pedunculate heads, calyx and corolla glabrous, scented. Pods are indehiscent, straight or curved, 4-7.5 cm length, about $1.5 \mathrm{~cm}$ width, dark brown to blackish, glabrous, finely longitudinally striate, pointed at both ends. Seeds are chestnut brown, in 2 rows, embedded in a dry spongy tissue, 7-8 $\mathrm{mm}$ long, $5.5 \mathrm{~mm}$ broad, elliptic, thick, and slightly compressed. Areole $6.5-7 \mathrm{~mm}$ long, $4 \mathrm{~mm}$ wide [10]. A. farnesiana is one of the medicinally important plants of Ayurvedic system of medicine and has been used for various pharmacological activities such as Vibrio cholera inhibition [11], herbicide [12], antimalarial [13], antioxidant [14], antidiarrheal [15], antimicrobial [16], phytoremediation [17], defluoridation, adsorbent [18], antiulcer [19], acetylcholine esterase, NADH oxidase inhibitory [20], bronchodilator [21], and anti-inflammatory [22]. The compounds, viz., lectin-like protein, cyclopropenoid fatty acids [23], four new diterpenes, acasiane $\mathrm{A}$, acasiane $\mathrm{B}$, farnesirane $\mathrm{A}$, and farnesirane B [24], methyl gallate [25], naringenin, kaempferol, quercetin, and myricetin [26] have been isolated from various parts of the plant. In view of the above fact and literature survey revealed that phytochemicals present in A. farnesiana pod are active against many pharmacological activities, but so far no investigation on its antiproliferative potential has been made. Hence, in this investigation, the antiproliferative and DNA cleavage activity of A. farnesiana pods have been studied.

\section{METHODS}

\section{Chemicals}

The chemicals used were of analytical grade. Doxorubicin (Sigma-Aldrich, USA), Calf-thymus DNA (Bangalore Genei, India), 
dimethyl sulfoxide (DMSO), agarose, ethidium bromide (ETBr), and other chemicals were from (HiMedia Mumbai, India).

\section{Collection of plant material}

The pods of A. farnesiana were collected in the month of FebruaryMarch-2014 around Kadur town of Chikkamagaluru District, Karnataka State, India, and were authenticated with voucher specimen no KUYLK4409 at the Herbarium, Department of Botany, Kuvempu University, Shankaraghatta, Shimoga Dist. Karnataka State. India.

\section{Preparation of extract [27]}

The extraction of the pods was achieved by grinding the material of A. farnesiana pods (100 g), packed in Soxhlet extractor and extracted successively using different solvent, viz., n-hexane $(500 \mathrm{ml})$, dichloromethane (DCM) $(500 \mathrm{ml})$, and methanol $(500 \mathrm{ml})$ with their increasing order of polarity. The extraction of $A$. farnesiana pod was carried out by a Soxhlet extraction method successively for about $48 \mathrm{~h}$ or until the color discharge in the siphon tube of Soxhlet apparatus. The yield after evaporation of extracts was n-hexane $\left(\mathrm{S}_{1}\right)(0.45 \mathrm{~g})$, DCM $\left(\mathrm{S}_{2}\right)$ $(0.26 \mathrm{~g})$, and methanol $\left(\mathrm{S}_{3}\right)(1.77 \mathrm{~g})$. The obtained extracts were stored at $-4^{\circ} \mathrm{C}$ for further analysis.

Preparation of fractions $S_{4}$ and $S_{5}$ from $A$. farnesiana methanol extract

The crude methanol extract of $A$. farnesiana pod was dissolved in $10 \%$ of sodium bicarbonate solution and kept overnight to undergo precipitation and later centrifuged to separate the precipitate. The precipitate was dissolved in water and extracted with ethyl acetate. The ethyl acetate extract was evaporated to dryness, and the dried mass was dissolved in methanol to yield two fractions one is methanol soluble fraction designated as $\mathrm{S}_{4}$ and another methanol insoluble fraction designated as $\mathrm{S}_{5}$.

\section{Phytochemical screening}

Preliminary phytochemical screening of A. farnesiana pod was performed according to the reported methods of Trease and Evans [28] and Harborne [29]. The phytochemical screening results are represented in Table 1.

\section{Antiproliferative activity by MTT assay}

Cell proliferation is the process where the number of cells increases or uncontrolled cell growth takes place due to an imbalance in the cellular mechanism, to control the growth of cells antiproliferative measures have been carried out using various cell lines [30]. The four different cell lines that were used in the study are colorectal adenocarcinoma (Colo 205); chronic myelogenous leukemia (K562); breast adenocarcinoma (MCF7); and hepatocellular carcinoma (HepG2). The cell lines were obtained from the National Centre for Cell Sciences, Pune, India, and were cultured at a seeding density of $0.2 \times 106$ in Dulbecco's

Table 1: Phytochemical screening of various solvent extracts of A. farnesiana pod and fraction of methanol extract

\begin{tabular}{lllllll}
\hline Test & Phytochemical test & $\mathbf{S}_{1}$ & $\mathbf{S}_{2}$ & $\mathbf{S}_{3}$ & $\mathbf{S}_{4}$ & $\mathbf{S}_{5}$ \\
\hline Alkaloids & Mayer's test & - & - & - & - & - \\
& Wagner's test & - & - & - & - & - \\
Flavonoids & Ferric chloride test & - & - & + & + & - \\
& Alkaline test & - & - & + & + & - \\
Glycosides & Killer-Killan's test & - & - & + & - & + \\
& Bromine water test & - & - & + & - & + \\
Proteins & Xanthoproteic test & - & - & - & - & - \\
& Ninhydrin test & - & - & - & - & - \\
Steroids & Salkowski's test & + & + & + & + & - \\
& Liebermann Burchard test & + & + & + & + & - \\
Tannins & Ferric chloride test & - & - & - & - & - \\
Saponins & Foam test & - & - & - & - & + \\
\hline
\end{tabular}

$\mathrm{S}_{1}$ - n-hexane extract, $\mathrm{S}_{2}$ - DCM extract, $\mathrm{S}_{3}$ - methanol extract, $\mathrm{S}_{4}$ - fraction

of methanol extract (methanol soluble), and $S_{5}$ - fraction of methanol

extract (methanol insoluble), A. farnesiana: Acacia farnesiana modified Eagles Medium/Roswell Park Memorial Institute medium supplemented with $10 \%$ fetal bovine serum, $100 \mathrm{U} / \mathrm{ml}$ penicillin, and $100 \mu \mathrm{g} / \mathrm{ml}$ streptomycin, respectively, maintained in a humidified atmosphere with $5 \% \mathrm{CO}_{2}$ at $37^{\circ} \mathrm{C}$. The samples were dissolved in DMSO (DMSO; not exceeding the final concentration of $0.01 \%$ ) and further diluted in cell culture medium. The antiproliferative response of the extract was assessed by MTT assay [3-(4, 5-dimethylthiazole-2yl) - 2, 5-diphenyltetrazolium bromide] [31]. Cells $(\sim 10,000)$ were plated in $200 \mu \mathrm{l}$ growth medium in the presence or absence of the extract $(25,50,100$, and $200 \mu \mathrm{g} / \mathrm{ml})$ in 96 -well culture plates for $24 \mathrm{hrs}$. Then, the culture plates were centrifuged at $2000 \mathrm{rpm}$ for 10 minutes at room temperature. Supernatant $(100 \mu \mathrm{l})$ was discarded, and $20 \mu \mathrm{l}$ of MTT ( $5 \mathrm{mg} / \mathrm{ml}$ in PBS) was added to each well and incubated for $4 \mathrm{hrs}$ at $37^{\circ} \mathrm{C}$. The viability of the cells was determined at $570 \mathrm{~nm}$ using a spectrophotometer.

\section{DNA cleavage activity by agarose gel electrophoresis}

The extract was added separately to the DNA sample. The sample mixtures were incubated at $37^{\circ} \mathrm{C}$ for $2 \mathrm{hrs}$. The treatment of DNA samples using electrophoresis was done according to the method adopted by Sambrook et al. [32]. Weigh $250 \mathrm{mg}$ of agarose and dissolve in $25 \mathrm{ml}$ of triacetate ethylenediamine (TAE) buffer (4.84 g Tris base, $\mathrm{pH}$ 8.0, $0.5 \mathrm{M}$ EDTA/1: l) by gentle heating. As the gel attains $\sim 55^{\circ} \mathrm{C}$, pour it into the gel cassette fitted with comb and allow solidifying. Carefully remove the comb, place the gel in the electrophoresis chamber flooded with TAE buffer. Load $20 \mu \mathrm{l}$ of DNA sample (mixed with bromophenol blue dye at 1:1 ratio) into the wells, along with DNA marker and pass the constant $50 \mathrm{~V}$ of electricity for around 45 minutes. After 45 minutes remove the gel and stain with ETBr solution $(10 \mu \mathrm{g} / \mathrm{ml})$ for $10-15$ minutes and observe the bands under UV transilluminator.

\section{RESULTS}

\section{Phytochemical screening}

Phytochemical screening of various solvent extracts of A. farnesiana as well as subfractions of the extract was carried out according to the methods adopted by Trease and Evans [28] and Harborne [29]. The presence of phytochemicals in various solvent extracts reveals the class of compounds present. The preliminary screening results revealed that the n-hexane and DCM extracts showed the presence of steroids, methanol extract revealed the presence of flavonoids, steroids, and glycosides whereas the methanol soluble fraction of methanol extract revealed the presence of flavonoids and steroids. The methanol insoluble portion has shown a positive test for glycosides and saponins.

\section{Antiproliferative activity}

The result for antiproliferative activity of various solvent extracts of A. farnesiana pod on different cancer cell lines was tested. The n-hexane extract $\left(\mathrm{S}_{1}\right)$ inhibited chronic myelogenous leukemia (K562) by $6.41 \%$, hepatocellular carcinoma (HePG2) by $10.81 \%$, breast cancer (MCF-7) by $21.7 \%$, and colorectal adenocarcinoma (Colo 205) by 4.7\%. DCM extract $\left(\mathrm{S}_{2}\right.$ ) inhibited chronic myelogenous leukemia (K562) by 4.93\%, breast cancer (MCF-7) by 19.36, colorectal adenocarcinoma (Colo 205) by $6.93 \%$, and no inhibition against hepatocellular carcinoma (HePG2). Methanol extract $\left(\mathrm{S}_{3}\right)$ inhibited chronic myelogenous leukemia (K562) by $24.53 \%$, hepatocellular carcinoma (HePG2) by $23.34 \%$, and breast cancer (MCF-7) by 17.6\%. The results are represented in Table 2.

\section{DNA cleavage activity}

The result for DNA cleavage activity by various solvent extracts of A. farnesiana pod demonstrates that $n$-hexane extract $\left(S_{1}\right)$ cleaved the DNA at the concentrations tested; DCM extract $\left(\mathrm{S}_{2}\right)$ also cleaved the DNA at the concentrations tested, but a very prominent low molecular weight DNA band formation was seen with the increasing concentration of the sample. The methanol extract $\left(\mathrm{S}_{3}\right)$ has increased the DNA cleavage potential with an increase in the concentration of the sample. The fraction $\left(S_{4}\right)$ has shown partial, but significant DNA cleavage as shown in Fig. 1 and in fraction $\left(S_{5}\right)$ DNA cleavage is significant at $100 \mu$ g, but other two concentrations yielded less significant cleavage as shown in 
Fig. 2. Overall the results reveal that the DNA cleavage potential was found in the extracts of $A$. farnesiana pod. The activity exhibited by the extracts was found to be dose dependent. The fractions $\mathrm{S}_{4}$ and $\mathrm{S}_{5}$

Table 2: Percentage inhibition of antiproliferative activity by different solvent extracts of $A$. farnesiana pods

\begin{tabular}{|c|c|c|c|c|}
\hline $\begin{array}{l}\text { Cancer cell } \\
\text { lines }\end{array}$ & $S_{1}$ & $S_{2}$ & $S_{3}$ & Doxorubicin \\
\hline \multicolumn{5}{|l|}{ K562 } \\
\hline Average \% in & 6.411779 & 4.939444 & 24.53099 & 95.57 \\
\hline SD & 1.067045 & 3.575294 & 2.809822 & 2.2256 \\
\hline \multicolumn{5}{|l|}{ MCF - 7} \\
\hline Average $\%$ in & 21.70372 & 19.36195 & 17.42746 & 97.61 \\
\hline SD & 3.839193 & 2.922661 & 1.760558 & 2.189 \\
\hline \multicolumn{5}{|l|}{ Colo } \\
\hline Average \% in & 4.744526 & 6.934307 & NA & 91.55 \\
\hline SD & 3.171195 & 1.860956 & & 1.8723 \\
\hline \multicolumn{5}{|l|}{ HepG2 } \\
\hline Average \% in & 10.81081 & NA & 23.34152 & 97.355 \\
\hline SD & 3.898994 & & 1.890455 & 1.5699 \\
\hline
\end{tabular}

$\mathrm{S}_{1}$ - n-hexane extract, $\mathrm{S}_{2}$ - DCM extract, and $\mathrm{S}_{3}$ - methanol extract, NA: Not active, SD: Standard deviation, A. farnesiana: Acacia farnesiana

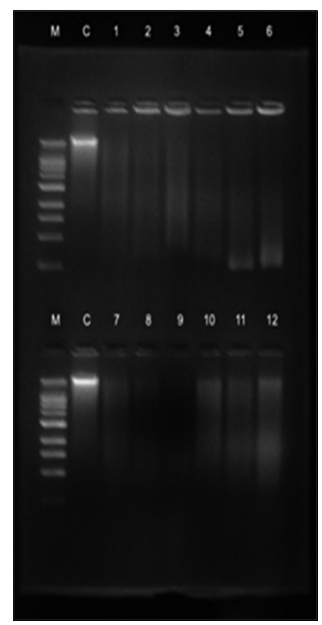

Fig. 1: DNA cleavage potential of various solvent extracts of $A$. farnesiana pods and its fraction $\mathrm{S}_{4}$ against CT - DNA. (1-3)

Sample $S_{1}$ at 25,50 and $100 \mu \mathrm{g}$, (4-6) sample $S_{2}$ at 25,50 and $100 \mu \mathrm{g},(7-9)$ sample $S_{3}$ at 25,50 and $100 \mu \mathrm{g},(10-12)$ sample $S_{4}$ at 25,50 and $100 \mu \mathrm{g}$

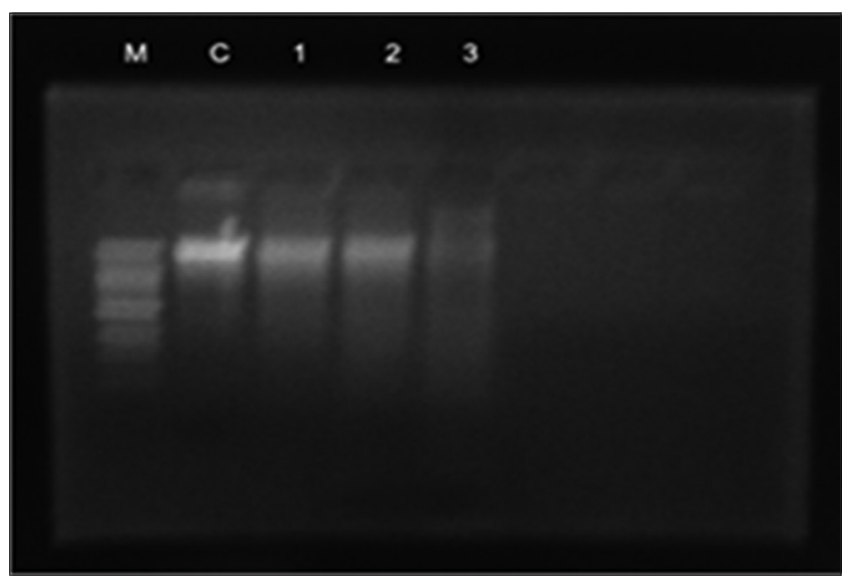

Fig. 2: DNA cleavage potential of fraction $S_{5}$. (1-3) Sample $S_{5}$ at 25 50, and $100 \mu \mathrm{g}, \mathrm{M}$ - super mix DNA Ladder (Merck, Cat \# MBD21J), C - CT-DNA, $S_{1}$ - $n$-hexane extract, $S_{2}$ - DCM extract, $S_{3}$ - methanol extract, $S_{4}$ - fraction of methanol extract (methanol soluble), and $S_{5}$ - fraction of methanol extract (methanol insoluble) were found to be less potential than their extracts even though they are partially purified fractions of methanol extracts. The methanol extract is worth investigating to further fractionate using methods adopted for compounds of specific classes which might increase the cleavage potential at very low concentration and isolate compounds which might be having better activity than the extract.

\section{DISCUSSION}

Cancer is a deadly disease which affects a considerable number of people worldwide. The ongoing research is to seek out effective treatments for cancer including the use of medicinal plants. This treatment makes use of the compounds naturally present in plants that are known to inhibit or kill carcinogenic cells [33]. The phytochemical screening of the plant showed the presence of flavonoids, steroids, and glycosides (Table 1). Flavonoids are effective in inhibiting xanthine oxidase, [34] cyclooxygenase [35] enzymes. The molecular mechanism may involve the inhibition of the pro-oxidant process that causes tumor promotion. Growth promoting oxidants and reactive oxygen species are the major catalysts of the tumor promotion and progression stages and therefore inhibit tumor cell proliferation. In addition, the mechanism of inhibition of polyamine biosynthesis can contribute to the antiproliferative activities of flavonoids. Ornithine decarboxylase is a rate-limiting enzyme in polyamine biosynthesis and is correlated with the rate of DNA synthesis and cell proliferation in several tissues. Several experiments show that flavonoids can inhibit ornithine decarboxylase induced by tumor promoters causing a subsequent decrease in polyamine and inhibition of DNA and protein synthesis [36-38]. Cardiac glycosides or steroids may bind to $\mathrm{Na}^{+}$and $\mathrm{K}^{+}$ion ATPase results in complex but well-documented changes in cell signaling events. The "signalosome" complex includes the enzyme, $\mathrm{Na}^{+}, \mathrm{K}^{+}$- ATPase as well as, phosphoinositide-3 kinase, and phospholipase each of which, in turn, sets into action complex signaling events that can result in tumor cell death through either apoptosis or autophagy-related mechanisms [39]. The evaluation is carried out by dissolving the extracts in DMSO (DMSO; not exceeding the final concentration of $0.01 \%$ ) and further diluted in cell culture medium. The antiproliferative response of the extract was assessed by MTT assay using doxorubicin as a standard drug molecule. The viability of the cells was determined using a spectrophotometer at $570 \mathrm{~nm}$. The inhibitory concentration $50 \%$, that is, the concentration of the extract required to inhibit cell growth by $50 \%$, was determined. This study has assessed the antiproliferative and DNA cleavage potential of various extracts and fractions of $A$. farnesiana pod. The n-hexane $\left(\mathrm{S}_{1}\right)$, DCM $\left(\mathrm{S}_{2}\right)$, and methanol $\left(\mathrm{S}_{3}\right)$ have shown less significant activity against different cell lines that are chronic myelogenous leukemia (K562), hepatocellular carcinoma (HePG2), breast cancer (MCF-7), and colorectal adenocarcinoma (Colo 205) cell lines but methanol and n-hexane have shown significant activity against chronic myelogenous leukemia (K562), hepatocellular carcinoma (HePG2), and breast cancer (MCF-7). From the above result, we can predict that the inhibition of chronic myelogenous leukemia (K562) and hepatocellular carcinoma (HePG2) by methanolic extract is found to be most effective and the inhibition of breast cancer (MCF-7) by N-Hexane extract is the best among the extracts screened. As the concentration of the sample increases, there is an increase in the cell growth inhibition for all the cell lines. The above findings indicate that the activity exhibited by the extracts might be because of their inhibitory effects of the enzymes by the phytochemicals. The potentiality of the extract still encourages for further investigation even though the extracts is having a moderate degree of activity.

DNA is the primary target molecule for anticancer therapies according to cell biology. Binding of peptides and small organic molecules to DNA will interfere with a number of processes like transcription and replication by considering this principle, various disorders such as cancer, and cystic fibrosis can be cured [40]. The literature survey reveals that the clinical efficacies of many drugs correlate with their ability to induce enzyme-mediated DNA cleavage. The loci present in the DNA are involved in various regulatory processes such as gene 
expression, gene transcription, mutagenesis, and carcinogenesis [41]. In particular, designing of the compound having ability to cleave DNA is utmost important not only from the primary biological point of view but also in terms of photodynamic therapeutic approach to develop potent drugs [42]. The extracts which were found to be active in CT-DNA cleavage have been screened for their antiproliferative study. The DNA cleavage of various solvent extracts of $A$. farnesiana pod like n-hexane, DCM and methanol studied were actively cleaved, but fractions are not effective, hence the antiproliferative studies are conducted only for crude extract, viz., $\left(\mathrm{S}_{1}, \mathrm{~S}_{2}\right.$, and $\left.\mathrm{S}_{3}\right)$ represented in Fig. 1 . The cleavage potential of the extracts was examined by comparing the band appeared in control and extracts at $100 \mu \mathrm{g}$ concentration. The DNA cleavage might be through the oxidation of deoxyribose by abstraction of sugar hydrogen or oxidation of nucleobases. Cleavage can occur both at the carbohydrate and at the nucleic base levels. This mechanism results in the damage of all four nucleobases or the deoxyribose sugar. In general, hydroxyl radical species of $\mathrm{O}_{2}(\mathrm{OH})$ are involved. The phytochemical screening of extracts and fractions indicated the presence of flavonoids, steroids, and glycosides which contain hydroxyl groups in their structures may initiate them for oxidative DNA cleavage. The cleavage mechanism occurs in three ways hydrogen abstraction, addition, and electron transfer. The general accepted mechanism of the DNA hydrolysis reaction is a nucleophilic attack [40]. Cleavage at DNA phosphate backbone: To form a five coordinate intermediate, this can be stabilized by the catalyst. Subsequent cleavage of either the 3'-phosphate (as seen is most often in enzymatic systems) or the 5 '-phosphate results in a strand scission. After this nucleophilic attack, one group leaves as an alcohol [40]. Cleavage at deoxyribose sugar: If the oxidative cleavage occurs at the carbohydrate, abstraction of one hydrogen of deoxyribose can initiate the oxidative cleavage process. The oxidation at the nucleic base level occurs preferably at guanine because it's lower oxidation potential. Hydroxyl radical reacts with the heterocyclic bases in DNA by addition. In pyrimidines, $\mathrm{OH}$ adds to the $\mathrm{C}_{5}$ or $\mathrm{C}_{6}$ double bond leading to cleavage. In purines, the cleavage occurs when hydroxyl ion binds to the $\mathrm{C}_{4}, \mathrm{C}_{5}$, and $\mathrm{C}_{8}$ [43]. The activity exhibited by the extracts and its fractions does not completely explain the mechanism of action. Based on the results obtained it can be stated that the flavonoids, steroids, and glycosides do contain $\mathrm{OH}$ functionality hence, might be involved in DNA cleavage as mentioned above. Further conclusive research needs to be carried out to attain final conclusion about the activity of DNA cleavage for A. farnesiana extracts.

\section{CONCLUSION}

The results obtained have shown that out of three extracts screened the two, viz., $\mathrm{n}$ - hexane and methanol of A. farnesiana pod have significant inhibition, and DCM has less significant on different cancer cell lines. The isolation of particular phytochemical from these two extracts can give the compound which is responsible for the inhibition of the three cancer cell lines chronic myelogenous leukemia (K562), hepatocellular carcinoma (HePG2), and breast cancer (MCF-7). The DNA cleavage is found to be effective with all the extracts, especially with $\mathrm{S}_{1}$ and $\mathrm{S}_{3}$ comparing to $\mathrm{S}_{2}, \mathrm{~S}_{4}$, and $\mathrm{S}_{5}$. Thus, A. farnesiana pod is concluded to be significant cytotoxic against the four cell lines mentioned above by MTT assay, and the DNA cleavage by various extracts and the fractions are found to cleave significant at all concentrations.

\section{ACKNOWLEDGMENT}

The authors are thankful to the authorities of Kuvempu University, for providing necessary facilities to carry out this work, Professor Y. L. Krishnamurthy, Department of Applied Botany Kuvempu University, for authentication of plant material and one of the authors S. P. Soul Shekhar is also thankful to OBC Cell Kuvempu University, for awarding $\mathrm{OBC}$ fellowship to carry out $\mathrm{Ph}$. D. programme.

\section{REFERENCES}

1. Gennari C, Castoldi D, Sharon O. Natural products with taxol-like antitumor activity: Synthetic approaches to eleutherobin and dictyostatin. Pure Appl Chem 2007;79(2):173-80.
2. Nishanthi M, Prasanthi $P$, Muni TK, Kumar RK, Nishanthi P, Nagendramma M, et al. A cancer disease: A review. Asian J Pharm Res 2013;3(1):47-52

3. Global Cancer Facts and Figures. $3^{\text {rd }}$ ed. Atlanta: American Cancer Society; 2015. Available from: https://www.cancer.org/research/cancerfacts-statistics/global.html.

4. Dai J, Mumper RJ. Plant phenolics: Extraction, analysis and their antioxidant and anticancer properties. Molecules 2010;15(10):7313-52.

5. Nostro A, Germano MP, Angelo VD, Marino A, Cannatelli MA. Extraction methods and bioautography for evaluation of medicinal plant antimicrobial activity. Lett Appl Microbiol 2000;30(5):379-84.

6. Edeoga HO, Okwu DE, Mbaebie BO. Phytochemical constituents of some Nigerian medicinal plants. Afr J Biotechnol 2005;4(7):685-8.

7. Kaur R, Kapoor K, Kaur H. Plants as a source of anticancer agents. J Nat Prod Plant Resour 2011;1(1):119-24.

8. Harun-ur-Rashid M, Gafur MA, Golam S, Aziz AR. Biological activities of a new acrylamide derivative from Ipomoea turpethum. Pak J Biol Sci 2002;5(9):968-9.

9. Bino K, Saminathan K, Pemaiah B, Appian S. Pharmacodynamic studies on the isolated active fraction of Acacia farnesiana (L.) Willd. Pharmacogn Mag 2014;10 Suppl S2:S283-7.

10. Duke JA. Handbook of Legumes of World Economic Importance. $1^{\text {st }}$ ed. New York: Plenum Press; 1981.

11. Santos G, Ginebra A, Cristina R, Norma H. Extracts of Acacia farnesiana and Artemisia ludoviciana inhibit growth, enterotoxin production and adhesion of Vibrio cholera. World J Microbiol Biotechnol 2006;22:669-74.

12. Allan S, Adkins S. Searching for a Natural Herbicide: The Role of Medicinal Plants. School of Land and Food Science, University of Queensland, St. Lucia Qld 4072. Available from: http://www.regional. org.au/au/allelopathy/2005/2/7/2680 allans.htm.

13. Garavito G, Rincon J, Arteaga L, Hata Y, Bourdy G, Gimenez A, et al. Antimalarial activity of some colombian medicinal plants. J Ethnopharmacol 2006;107(3):460-2.

14. Salfarina R, Ken-Ichi H, Nijsiri R. Antioxidant, antimicrobial and cytotoxicity activities of Acacia farnesiana (L.) Willd. Leaves ethanolic extract. Pharmacogn J 2011;3(23):50-8.

15. de la Steve C, Eduardo R, Hortencia ND, Adela AV. Acute toxicity and decreased peristalsis in mice caused by Taxodium mucronatum and Acacia farnesiana extracts. Rev Latinoam Quím 2012;40(1):19-25.

16. Thirupal RB, Varaprasad B, Moulali DA. Antimicrobial screening of Acacia farnesiana (L.) Willd. Indian J Bot Res 2008;4(2):249-51.

17. Amalia MM, Ernesto FT, Fernando RC, Tania LV. Lead bioaccumulation in Acacia farnesiana and its effect on lipid peroxidation and glutathione production. Plant Soil 2011;339(1):377-89.

18. Hanumantharao Y, Medikondu K, Ravindhranath K. Characterization an defluoridation studies using activated Acacia farnesiana carbon as adsorbent. Electron J Environ Agric Food Chem 2012;11:442-58.

19. Dwarakanath V, Dhanasree B, Jayasimha GB, Nizamuddin BS. Antiulcer activity of Acacia farnesiana (L) (aroma) a lesser known folk - Medicinal plant. Int J Pharm Bio Sci 2013;3:145-52.

20. Nashrin T, Syahiran R. Inhibition of acetylcholine esterase and NADH oxidase by Acacia farnesiana. Panacea J Pharm Pharm Sci 2012;1:6-8.

21. Trivedi CP, Modi NT, Sarin RK, Rao SS. Bronchodilator and antiinflammatory effect of glycosidal fraction of Acacia farnesiana. Indian J Physiol Pharm 1986;30(3):267-8.

22. Abrantes VE, Rocha BA, Nóbrega RB, Silva-Filho JC, Teixeira CS, Cavada BS, et al. Molecular modeling of lectin-like protein from Acacia farnesiana reveals a possible anti-inflammatory mechanism in carrageenan-induced inflammation. BioMed Res Int 2013;2013:253483.

23. Kariyappa SK, Kallappa MH. Occurrence of cyclopropenoid fatty acids in Acacia farnesiana seed oil and its possible industrial utilization. Indian J Appl Res 2013;3:72-4

24. Shen LA, Rong LC, Chi DY, Tilo L, Michael YC, Chenb IH, et al. Acasiane $\mathrm{A}$ and $\mathrm{B}$ and farnesirane $\mathrm{A}$ and $\mathrm{B}$, diterpene derivatives from the roots of Acacia farnesiana. Plant Med 2009;75(3):256-61.

25. Sanchez E, Heredia N, Mdel RC, Garcia S. Isolation, characterization and mode of antimicrobial action against Vibrio cholerae of methyl gallate isolated from Acacia farnesiana. J Appl Microbiol 2013;115(6):1307-16.

26. Heba HB, Ahmed MS, Sahar AM, Ola AI, Mahmoud AM. Flavonoid galloyl glucosides from the pods of Acacia farnesiana. Phytochemistry 1999;51(1):139-42.

27. Satyanarayan ND, Al-Baadani WA, Shekhar SP, Harishkumar S. Antitubercular activity of various solvent extracts of Acalypha indica $\mathrm{L}$. Against drug susceptible H37Rv strain. World J Pharm Pharm Sci 2016;5(8):957-65. 
28. Trease GE, Evans WC. A Textbook of Pharmacognosy. $14^{\text {th }}$ ed. London: Bailliere Tindall Ltd.; 1996.

29. Harborne JB. Phytochemical Methods: A Guide to Modern Techniques of Plant Analysis. $3^{\text {rd }}$ ed. London: Chapman and Hall; 1998.

30. Manjunatha KS, Manjulatha K, Satyanarayan ND, Kaviraj MY, Adarsha HJ. Anti-proliferative and ADMET screening of novel 3-(1H-indol-3-yl)-1, 3-diphenylpropan-1-one derivatives. Cogent Chem 2016;2:1172542.

31. Anantacharya R, Manjulatha K, Satyanarayan ND, Santoshkumar S, Kaviraj MY. Antiproliferative, DNA cleavage, and ADMET study of substituted 2-(1-benzofuran-2-yl) quinoline-4-carboxylic acid and its esters. Cogent Chem 2016;2:1158382.

32. Sambrook J, Fritsch EF, Maniatis T. Molecular Cloning: A Laboratory Manual. $2^{\text {nd }}$ ed. New York: Cold Spring Harbor Laboratory; 1989.

33. Umadevi M, Kumar KP, Bhowmik D, Duraivel S. Traditionally used anticancer herbs in India. J Med Plant Stud 2013;1(3):56-74.

34. Chang WS, Lee YJ, Lu FJ, Chiang HC. Inhibitory effects of flavonoids on xanthine oxidase. Anticancer Res 1993;13(6A):2165-70.

35. Mutoh M, Takahashi M, Fukuda K, Komatsu H, Enya T, Matsushima HY, et al. Suppression by flavonoids of cyclooxygenase-2 promoter-dependent transcriptional activity in colon cancer cells: Structure-activity relationship. Jpn J Cancer Res 2000;91(7):686-91.

36. Tanaka T, Makita H, Kawabata K, Mori H, Kakumoto M, Satoh K, et al. Chemoprevention of azoxymethane-induced rat colon carcinogenesis by the naturally occurring flavonoids, diosmin and hesperidin.
Carcinogenesis 1997;18(5):957-65.

37. Tanaka T, Makita H, Ohnishi M, Mori H, Satoh K, Hara A, et al. Chemoprevention of 4-nitroquinoline 1-oxide-induced oral carcinogenesis in rats by flavonoids diosmin and hesperidin, each alone and in combination. Cancer Res 1997;57(2):246-52.

38. Makita H, Tanaka T, Fujitsuka H, Tatematsu N, Satoh K, Hara A, et al. Chemoprevention of 4-nitroquinoline 1-oxide-induced rat oral carcinogenesis by the dietary flavonoids chalcone, 2-hydroxychalcone, and quercetin. Cancer Res 1996;56(21):4904-9.

39. Robert AN, Peiying Y, Alison DP, Keith IB. Cardiac glycosides as novel cancer therapeutic agents. Mol Invent 2008;8(1):36-49.

40. Gowda KR, Blessy BM, Sudhamani CN, Naik HS. Mechanism of DNA binding and cleavage. Biomed Biotechnol 2014;2(1):1-9.

41. Sreelatha S, Padma PR, Umadevi M. Protective effects of Coriandrum sativum extracts on carbon tetrachloride-induced hepatotoxicity in rats. Food Chem Toxicol 2009;47(4):702-8

42. Kumar V, Kaur K, Karelia DN, Beniwal V, Gupta GK Arun KS, et al. Synthesis and biological evaluation of some 2-(3, 5-dimethyl-1H-pyrazol-1-yl)-1 arylethanones: Antibacterial, DNA photocleavage, and anticancer activities. Eur J Med Chem 2014;81:267-76.

43. Kochetkov NK, Budovskii EI. Reactions involving the cleavage or rearrangement of heterocyclic rings of nucleic acid bases and their derivatives. Organic Chemistry of Nucleic Acids. $1^{\text {st }}$ ed. London: Plenum Publishing Company Ltd.; 1972. 